\title{
Bibliometric Analysis in Astrophysics: Overview of Education, Religion, and Local Wisdom in 2016-2021*
}

\author{
Zainuddin ${ }^{1}$, Surya Haryandi ${ }^{2}$, Misbah ${ }^{3}$, Mastuang ${ }^{4}$, Mohd Ali Ibrahim ${ }^{5}$, Emy Nur Juliana ${ }^{6}$, \\ Munawarah', and Ma'rifah Hidayati ${ }^{8}$ \\ 1,2,3,4,6,7,8 Lambung Mangkurat University, Banjarmasin, Indonesia \\ 5Physics Eduction, University Teknologi Malaysia, Malaysia
}

\begin{tabular}{|c|c|}
\hline 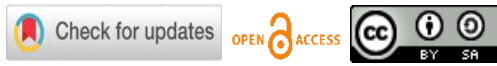 & DOI : https://doi.org/10.46245/ijorer.v2i5.140 \\
\hline Sections Info & \multirow{12}{*}{$\begin{array}{l}\text { Astrophysics education is one of the subjects in the physics education study } \\
\text { program which is also part of astronomy. Astrology is the structure and } \\
\text { epistemology of Islamic law that studies the sun, moon, stars, and celestial } \\
\text { bodies related to aspects of Islamic law. Indonesian Muslims cannot be } \\
\text { separated from local wisdom which is the wealth of the Indonesian nation. This } \\
\text { article intends to provide a comprehensive explanation through bibliometric } \\
\text { analysis of literature on astrophysics education, religion, and local wisdom. } \\
\text { Article searches are performed by Publish or Perish (PoP) software on the } \\
\text { Google Scholar database. The search and sorting results found } 23 \text { of the } 200 \\
\text { articles found in the 2016-2021* range. The results of data processing by PoP } \\
\text { software are then edited through the Mendeley Desktop software. The editing } \\
\text { results are then processed using VOSviewer software to obtain a visualization } \\
\text { of the distribution pattern and data mapping. Broadly speaking, this research } \\
\text { shows the projected direction of astrophysics education research if it is studied } \\
\text { with religious content based on the Qur'an and local wisdom and its further } \\
\text { development. The implications of this research can inspire researchers to study } \\
\text { astrophysics education in universities with the content of the Qur'an and local } \\
\text { wisdom so that studying science can help increase faith in God. }\end{array}$} \\
\hline Article history: & \\
\hline Submitted: July 31, 2021 & \\
\hline Final Revised: September 7, 2021 & \\
\hline Accepted: September & \\
\hline Published: September 30, 2021 & \\
\hline Keywords: & \\
\hline Bibliometric & \\
\hline Analysis & \\
\hline Religion & \\
\hline Local Wisdom & \\
\hline 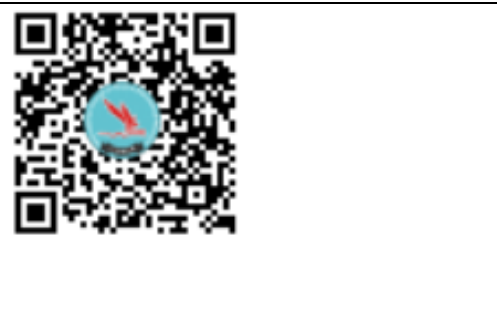 & \\
\hline
\end{tabular}

\section{INTRODUCTION}

When studying science, everything seems to be scientifically explained, even though until now there are still many phenomena that occur in the universe that science cannot explain. Al-Qur'an as a way of life for Muslims is not a book of science, but some problems in science are described and even detailed in it when science has not developed as advanced as it is now. Until now there are still those who believe that religion (faith) and science (rationality) are two things that cannot be met, let alone harmonized (Bujuri et al., 2020). Faith never contradicts rationality. Individuals who use rationality do not mean they don't have faith, nor do they use faith to oppose rationality. The meeting point of the two is when scientific discoveries that are full of rationality are directed to increase faith and piety to God (Bujuri et al., 2020; Lailiyah, 2020; Sabic-El-Rayess, 2020). One of the solutions needed by Islam to not be alienated from rationality is to study the philosophy of science. By studying the philosophy of science, people can recognize the purpose of the development of science so as to bring Islam to be the main actor in creating scientific concepts that can destroy the dividing wall between rationality and faith (Zaelani, 2015).

Today's scientists have to admit how shallow science is because the universe is much wider and bigger than what science can explain (Benz, 2017). Now the development of science and technology has reached the 21st century. 21st century skills that are currently needed in the world of education include critical thinking, problem solving, 
communication and collaboration skills, creative and innovative (Dona and Syafriani, 2020). In addition to 21st century skills, at the time this article was written, it had entered the era of the industrial revolution 4.0. The industrial revolution era had many positive impacts. The negative impact of the industrial revolution 4.0 era can be suppressed by integrating the Qur'an and science where some of the verses of the Qur'an have been successfully revealed and proven by modern science (Mukri et al., 2019).

Science is supported by morals and scientific ethics and is supported by integrity, honesty, openness, arguments, theories, and facts (Chusni et al., 2018). Stefano Gattei in his commentary on the philosophy of science put forward by Karl Popper revealed that metaphysics can be used to derive a hypothesis or not from an extraordinary scientific discovery (Prahani et al., 2020). An interesting approach in studying the integration of religion and modern science is the quantum approach offered by Nidhal Guessoum which is based on three principles (Soleh, 2018). The first principle, known as the principle of non-conflict, is used to juxtapose religion and science. The second principle, known as the principle of layered interpretation, is used to interpret the holy verses of the Qur'an from various perspectives and contexts. The third principle is known as the falsificative-theistic principle, it is used as a sign that must exist and be adhered to in science (Soleh, 2018). There are several interpretations of the Qur'an that are in line with modern astronomical findings, namely the interpretation of as-Shaukani $(1250 \mathrm{H} / 1834)$, Rashid Rida (1354H/1935), al-Maraghi (1371H/1951), Sayyid Qutb (1385H/1965), asSha'rawi (1418H/1997) and Az-Zuhaili (present) (Wahid et al., 2016). Not only that, the integration between science and religion is also reflected in the work of modern scientists such as Garv Zukav and Fritjof Capra (Toresano, 2020). Many scientific facts have been described in the Qur'an long before they were discovered by scientists, such as animal life, rain, natural phenomena, human processes in the mother's womb, etc. (Maimun, 2019).

Books and physics learning modules used today generally focus less on religious content because they tend to contain concepts, principles, and laws in science (Lizelwati and Chandra, 2019). In addition, the aspect of local wisdom as the wealth and noble values of the Indonesian nation still needs to be raised more in learning so that it can be passed on to the younger generation. The people of Banjarmasin hold local wisdom known as the slogan Baiman, Bauntung, Batuah which contains the characters needed in the field of education (Mastuang et al., 2019).

Based on the search results through the Google Scholar database in the 2016-2021* range, there are several bibliometric analysis articles related to astrophysics, namely the mapping of scientific communication (Mohan and Rajgoli, 2017), about the origin of life (Aydinoglu and Taşkın, 2018), and on the measurement of research activities (Henneken and Kurtz, 2019). Based on the data that has been collected from the Google Scholar database, no research has been found that describes the study of astrophysics education containing verses from the Qur'an and no bibliometric analysis of astrophysics education in the field of education has been found. In addition to these two things, based on data compiled from the Google Scholar database, studies on the integration of astrophysics education, the Qur'an, and local wisdom in Indonesia and abroad have not been found in the 2016-2021* range.

Departing from these three reasons, this article intends to provide a mapping of the distribution of astrophysics education research, examine astrophysics education in the perspective of Islam through the Qur'an and attempt to provide a comprehensive 
explanation through bibliometric analysis of literature on astrophysics education, religion, and local wisdom. Metadata obtained from the Google Scholar database is then analyzed and categorized based on author affiliation and distribution. Through this analysis, various astrophysical research trends can be identified and their opportunities for future research. This research methodology uses bibliometric analysis with Publish or Perish (PoP) software. The results of data processing by PoP are then edited through the Mendeley Desktop software. The editing results are then processed using VOSviewer software to obtain a visualization of the distribution pattern and data mapping. Finally, a discussion of the findings and conclusions are drawn based on the bibliometric analysis that has been carried out.

\section{RESEARCH METHOD}

\section{General Background}

A systematic and explicit method was chosen to review various literatures of bibliometric analysis (Garza-Reyes, 2015). The bibliometric analysis research method used is the adoption of the five-step method described in Figure 1 (Setyaningsih et al., 2018).

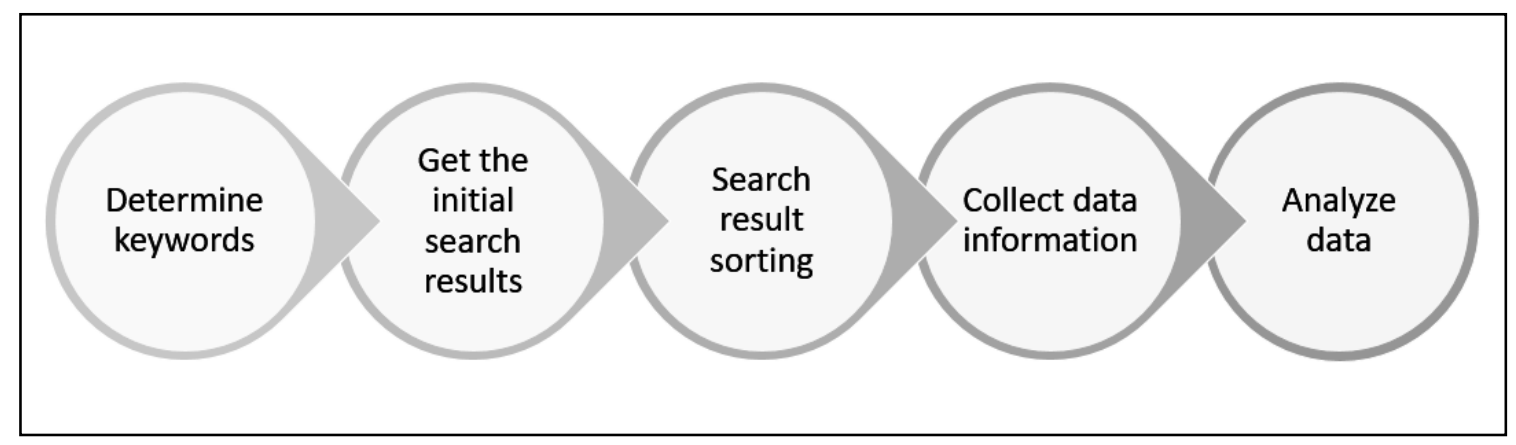

Figure 1. The five-stage method in bibliometric analysis.

\section{Sample / Participants / Group}

Literature and metadata search started in April 2021 with the keyword 'astrophysics education'. The Google Scholar database was chosen because it is the largest database that is also part of the world's largest and most popular search engine, Google. PoP software was chosen to perform the search because it proved to be the most effective in helping article metadata search (Baneyx, 2008). The search results are arranged in such a way on scientific articles published in the 2016-2021* range. The maximum search limit is set at 200 articles.

\section{Instrument and Procedures}

The search results are stored in Research Information Systems (RIS) format on the PoP software. The 200 articles were then sorted based on their publication media, namely scientific journals so that they became 161 articles. The second stage of sorting was carried out based on the relevance of the title to the realm of education and learning so that it became 23 articles. Sorting results are still stored in RIS format for further processing using the Mendeley Desktop software.

\section{Data Analysis}

RIS format data is processed by editing the metadata one by one article using Mendeley Desktop software. In the Mendeley Desktop software, the menu is selected to import data 
from the RIS format. Then Mendeley Desktop will parse the RIS-formatted data into one by one detailed reference list. Mendeley Desktop has another function, namely it can edit metadata from a reference list of book articles, proceedings, journals, etc. Incomplete metadata edited from title, author, journal name, year of publication, volume, series, pages, and abstracts are then completed to match the published article. Results from the Mendeley Desktop software are again saved in RIS format. The RIS-formatted data from the Mendeley Desktop software was then analyzed using the VOSviewer software. VOSviewer works by processing RIS-formatted data and then extracting selected keywords based on the title and abstract field from the article metadata. VOSviewer is used as an analytical tool because it is efficient and can display a variety of interesting and informative visualization results (Van Eck and Waltman, 2010).

\section{RESULTS AND DISCUSSION}

\section{Publications and Citation Structure}

In analyzing data in RIS format from the Mendeley Desktop software, VOSviewer software was used. VOSviewer can select the most frequently used keywords in searches stored in RIS formatted data. VOSviewer serves to display mapping visualizations from bibliometrics.

In the initial search results using PoP software, 200 articles were obtained from the Google Scholar database. The search result data is arranged in such a way in the 2016$2021^{*}$ range with the Indonesian language keyword, namely 'astrophysics education'. The first sorting was done based on the publication media, namely scientific journals so that it became 161 articles. It is known that from the 161 journal articles there were 1831.00 citations/year and 56.86 citations/articles. The second stage of sorting was carried out based on the relevance of the title to the realm of education and learning so that it became 23 articles. Of the 23 journal articles, there are 124.80 citations/year and 27.13 citations/articles.

The results of the comparison of output metric data from the first sorting and the second stage can be seen in Table 1.

Table 1. PoP metric data output comparison.

\begin{tabular}{lll}
\hline \multicolumn{1}{c}{ Data metrics } & \multicolumn{1}{c}{ First sorting } & \multicolumn{1}{c}{ Second sorting } \\
\hline Keywords & 'astrophysics education' & 'astrophysics education' \\
Publication year & $2016-2021^{*}$ & $2016-2021^{*}$ \\
Papers & 161 & 23 \\
Citations & 9155 & 624 \\
Cites/year & 1831,00 & 124,80 \\
Cites/paper & 56,86 & 27,13 \\
Author/paper & 3,45 & 2,43 \\
h_index & 53 & 14 \\
g_index & 92 & 23 \\
hI_norm & 26 & 10 \\
hI_annual & 5,20 & 2,00 \\
\hline
\end{tabular}

Based on the third-stage sorting data displayed by the PoP software, the following are systematically sorted articles that have the highest relevance to keywords to those with low relevance as can be seen in Table 2 . 
Table 2. Top 10 PoP sorting articles ranking.

\begin{tabular}{|c|c|c|c|c|c|c|}
\hline No & $\begin{array}{c}\text { Publication } \\
\text { year }\end{array}$ & Author & Title & Journal & Cites & Publisher \\
\hline 1 & 2016 & $\begin{array}{l}\text { Adrienne L. } \\
\text { Traxler, } \\
\text { Ximena C. } \\
\text { Cid, Jennifer } \\
\text { Blue, and } \\
\text { Ramón } \\
\text { Barthelemy }\end{array}$ & $\begin{array}{l}\text { Enriching gender } \\
\text { in physics } \\
\text { education } \\
\text { research: A } \\
\text { binary past and a } \\
\text { complex future }\end{array}$ & $\begin{array}{l}\text { Physical } \\
\text { Review } \\
\text { Physics } \\
\text { Education }\end{array}$ & 91 & APS \\
\hline 2 & 2018 & $\begin{array}{l}\text { Ulrich Rüde, } \\
\text { Karen Willcox, } \\
\text { Lois Curfman } \\
\text { McInnes, } \\
\text { Hans De } \\
\text { Sterck }\end{array}$ & $\begin{array}{l}\text { Research and } \\
\text { education in } \\
\text { computational } \\
\text { science and } \\
\text { engineering }\end{array}$ & $\begin{array}{c}\text { Siam } \\
\text { Review }\end{array}$ & 59 & SIAM \\
\hline 3 & 2018 & $\begin{array}{l}\text { Harendra } \\
\text { Singh }\end{array}$ & $\begin{array}{l}\text { An efficient } \\
\text { computational } \\
\text { method for the } \\
\text { approximate } \\
\text { solution of } \\
\text { nonlinear Lane- } \\
\text { Emden type } \\
\text { equations arising } \\
\text { in astrophysics }\end{array}$ & $\begin{array}{l}\text { Numerical } \\
\text { Methods } \\
\text { for Partial } \\
\text { Differentia } \\
1 \text { Equations }\end{array}$ & 52 & $\begin{array}{l}\text { Wiley } \\
\text { Online } \\
\text { Library }\end{array}$ \\
\hline 4 & 2016 & $\begin{array}{l}\text { Sharon P. } \\
\text { Fraser }\end{array}$ & $\begin{array}{l}\text { Pedagogical } \\
\text { content } \\
\text { knowledge } \\
\text { (PCK): Exploring } \\
\text { its usefulness for } \\
\text { science lecturers } \\
\text { in higher } \\
\text { education }\end{array}$ & $\begin{array}{l}\text { Research } \\
\text { in Science } \\
\text { Education }\end{array}$ & 51 & Springer \\
\hline 5 & 2016 & $\begin{array}{l}\text { K.S. Reddy, } \\
\text { En Xie, } \\
\text { Qingqing } \\
\text { Tang }\end{array}$ & $\begin{array}{l}\text { Higher } \\
\text { education, high- } \\
\text { impact research, } \\
\text { and world } \\
\text { university } \\
\text { rankings: a case } \\
\text { of india and } \\
\text { comparison with } \\
\text { china }\end{array}$ & $\begin{array}{c}\text { Pacific } \\
\text { Science } \\
\text { Review B: } \\
\text { Humanitie } \\
\text { s and } \\
\text { Social } \\
\text { Sciences }\end{array}$ & 50 & Elsevier \\
\hline 6 & 2017 & $\begin{array}{l}\text { Julia Mullen, } \\
\text { Chansup } \\
\text { Byun, Vijay } \\
\text { Gadepally, } \\
\text { Siddharth } \\
\text { Samsi, Albert } \\
\text { Reuther, }\end{array}$ & $\begin{array}{l}\text { Learning by } \\
\text { doing, high } \\
\text { performance } \\
\text { computing } \\
\text { education in the } \\
\text { MOOC era }\end{array}$ & $\begin{array}{l}\text { Journal of } \\
\text { Parallel } \\
\text { and } \\
\text { Distribute } \\
\text { d } \\
\text { Computin } \\
\text { g }\end{array}$ & 46 & Elsevier \\
\hline
\end{tabular}


Bibliometric Analysis in Astrophysics: Overview of Education, Religion, and Local Wisdom in 2016$2021^{*}$

\begin{tabular}{|c|c|c|c|c|c|c|}
\hline No & $\begin{array}{c}\text { Publication } \\
\text { year }\end{array}$ & Author & Title & Journal & Cites & Publisher \\
\hline 7 & 2018 & $\begin{array}{l}\text { Jeremy } \\
\text { Kepner } \\
\text { S. Psycharis }\end{array}$ & $\begin{array}{l}\text { STEAM in } \\
\text { education: A } \\
\text { literature review } \\
\text { on the role of } \\
\text { computational } \\
\text { thinking, } \\
\text { engineering } \\
\text { epistemology and } \\
\text { computational } \\
\text { science. } \\
\text { computational } \\
\text { steam pedagogy } \\
\text { (CSP) }\end{array}$ & $\begin{array}{l}\text { Scientific } \\
\text { Culture }\end{array}$ & 43 & core.ac.uk \\
\hline 8 & 2017 & E.L. Gomez & $\begin{array}{l}\text { Robotic } \\
\text { telescopes in } \\
\text { education }\end{array}$ & $\begin{array}{l}\text { Astronomi } \\
\text { cal Review }\end{array}$ & 42 & $\begin{array}{c}\text { Taylor \& } \\
\text { Francis }\end{array}$ \\
\hline 9 & 2019 & $\begin{array}{l}\text { Remy Dou, } \\
\text { Zahra Hazari, } \\
\text { Katherine } \\
\text { Dabney, } \\
\text { Gerhard } \\
\text { Sonnert, Philip } \\
\text { Sadler }\end{array}$ & $\begin{array}{l}\text { Early informal } \\
\text { STEM } \\
\text { experiences and } \\
\text { STEM identity: } \\
\text { The importance } \\
\text { of talking science }\end{array}$ & $\begin{array}{c}\text { Science } \\
\text { Education }\end{array}$ & 38 & $\begin{array}{l}\text { Wiley } \\
\text { Online } \\
\text { Library }\end{array}$ \\
\hline 10 & 2018 & $\begin{array}{l}\text { Julie Moote, } \\
\text { Louise Archer }\end{array}$ & $\begin{array}{l}\text { Failing to } \\
\text { deliver? } \\
\text { Exploring the } \\
\text { current status of } \\
\text { career education } \\
\text { provision in } \\
\text { england }\end{array}$ & $\begin{array}{l}\text { Research } \\
\text { Papers in } \\
\text { Education }\end{array}$ & 37 & $\begin{array}{c}\text { Taylor \& } \\
\text { Francis }\end{array}$ \\
\hline
\end{tabular}

The top 6 publishers of the PoP software sorting results on the topic of astrophysics education are shown in Table 3.

Table 3. Top 6 publishers in astrophysics education topics.

\begin{tabular}{clc}
\hline No & Publisher & Articles \\
\hline 1 & ui.adsabs.harvard.edu & 4 \\
2 & Taylor \& Francis & 3 \\
3 & APS & 3 \\
4 & Wiley Online Library & 2 \\
5 & Springer & 2 \\
6 & Elsevier & 2 \\
\hline
\end{tabular}

The top 2 publishers of the PoP software sorting results on the topic of astrophysics education are shown in Table 4. 
Table 4. Top 2 in astrophysics education topic.

\begin{tabular}{clcc}
\hline No & \multicolumn{1}{c}{ Journal } & Total articles & Cites \\
\hline 1 & Physical Review Education Research & 3 & 155 \\
2 & American Astronomical Society Meeting & 3 & 0 \\
Abstracts\# 228 & & \\
\hline
\end{tabular}

The mapping visualization of the metadata analysis results can be displayed with three different visualizations by the VOSviewer software (Hamidah et., 2020). The network visualization can be seen in Figure 2, the overlay visualization can be seen in Figure 3, and the density visualization can be seen in Figure 4.

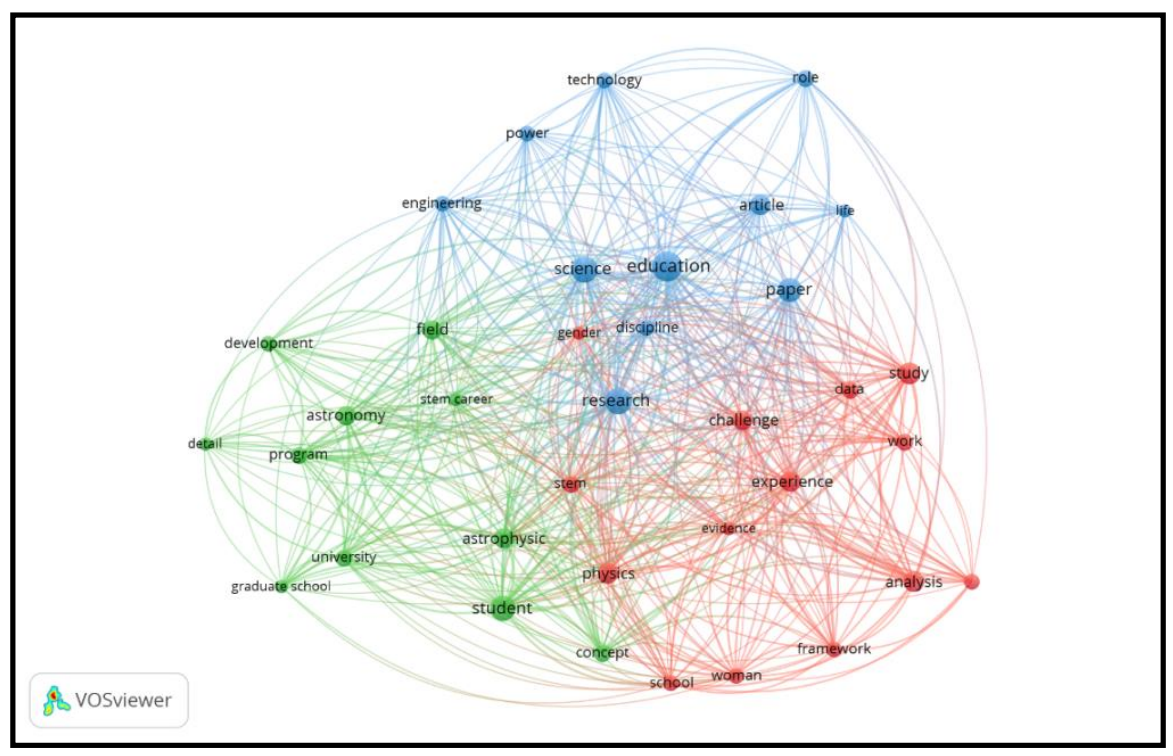

Figure 2. Network visualization on google scholar database.

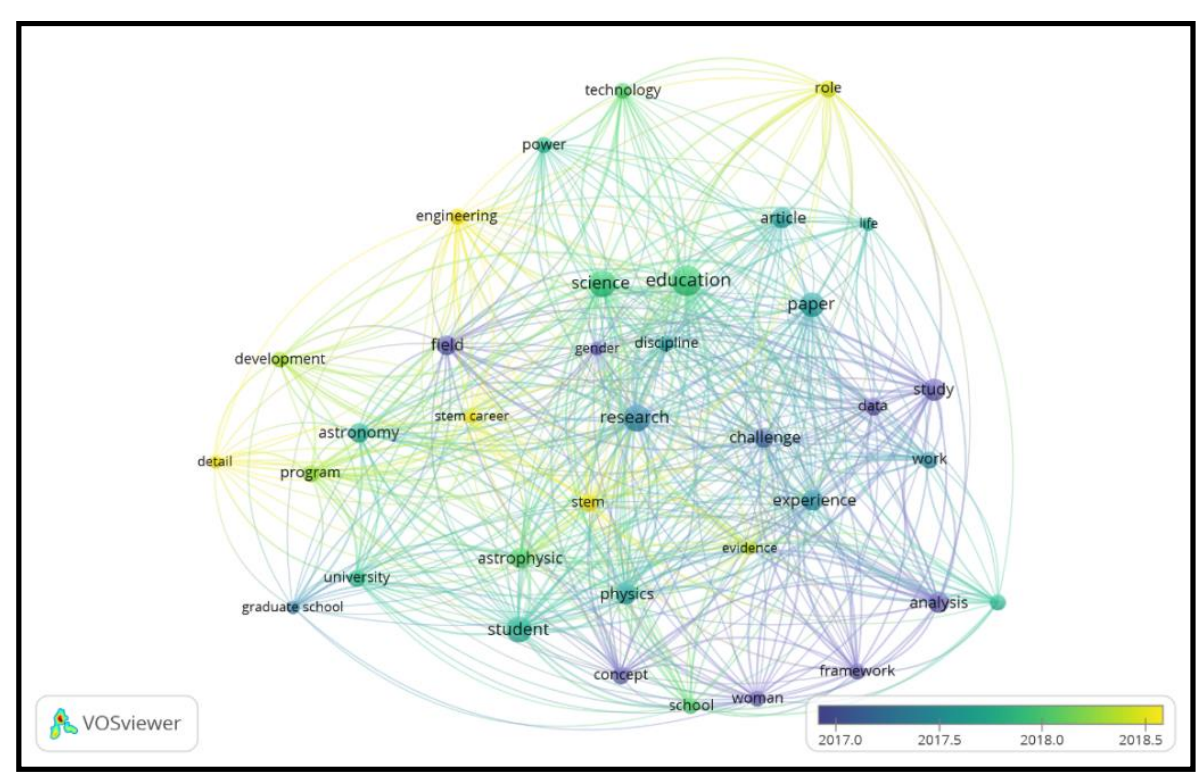

Figure 3. Overlay visualization on google scholar database. 


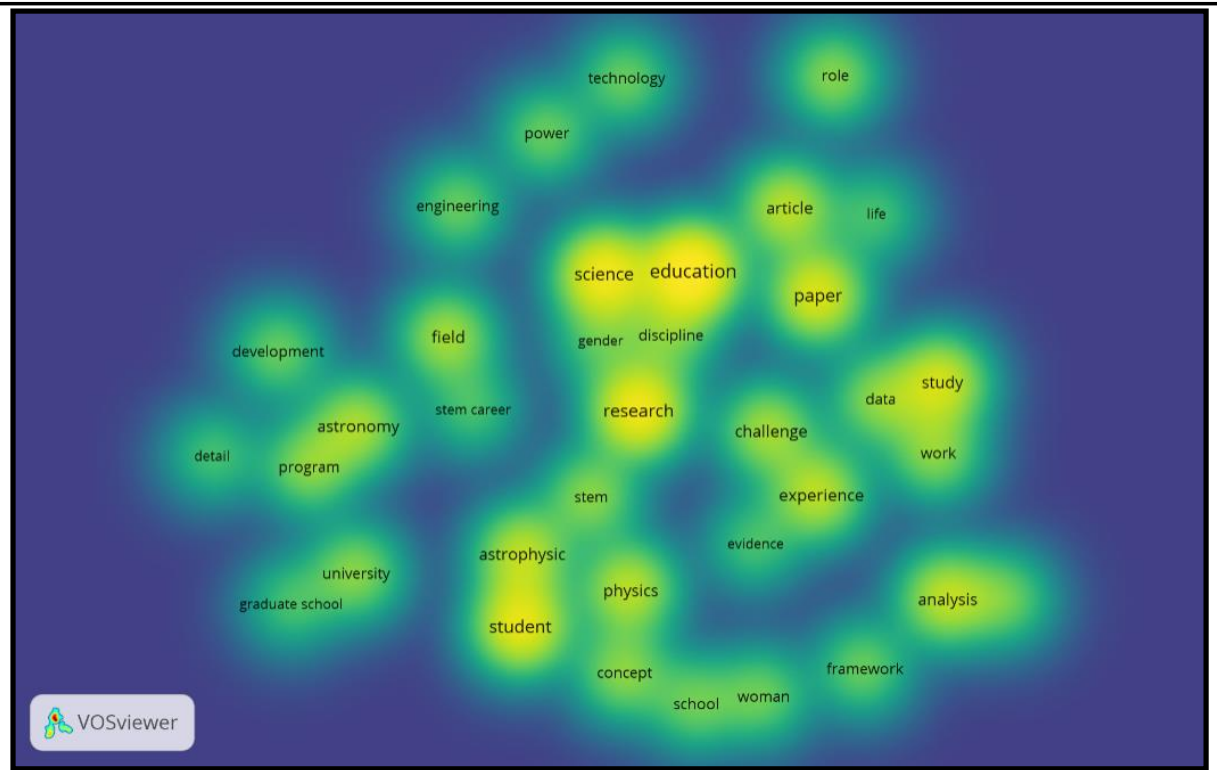

Figure 4. Density visualization on google scholar database.

The three types of visualization above are the results of VOSviewer software analysis by processing a number of 23 articles resulting from two-stage sorting and editing of metadata. The setting for the minimum number of events is set to 3 . The results of the analysis show that there are 36 items that meet the criteria that represent the keyword 'astrophysics education'. Based on Figure 2, 36 items that meet the keyword criteria are divided into 3 clusters with different colors, namely red, green, and blue. The development of astrophysics education research is clearly shown by each cluster which can be seen in Table 5 .

Table 5. Research development of each cluster.

\begin{tabular}{|c|c|c|c|}
\hline No & Cluster & Total item & Research element \\
\hline 1 & Red cluster & 14 & $\begin{array}{l}\text { analysis (7), challenge (6), data (5), evidence (3), } \\
\text { experience (7), framework (4), gender (3), higher } \\
\text { education (4), physics (7), school (4), stem (5), study } \\
(8) \text {, woman (4), work (5) }\end{array}$ \\
\hline 2 & Green cluster & 11 & $\begin{array}{l}\text { astronomy (6), astrophysics (7), concept (5), detail (3), } \\
\text { development (4), field (6), graduate school (3), } \\
\text { program (5), stem career (3), student (10, university } \\
(5)\end{array}$ \\
\hline 3 & Blue cluster & 11 & $\begin{array}{l}\text { article (7), discipline (4), education (14), engineering } \\
\text { (4), life (3), paper (9), power (4), research (11), role (5), } \\
\text { science (11), technology (4) }\end{array}$ \\
\hline
\end{tabular}

Author and co-author relationship

The author's analysis, co-authoring relationships and collaboration patterns between authors are visualized in Figure 5. Based on Figure 5, it can be seen that there are 9 groups of co-authors with varying colors. 


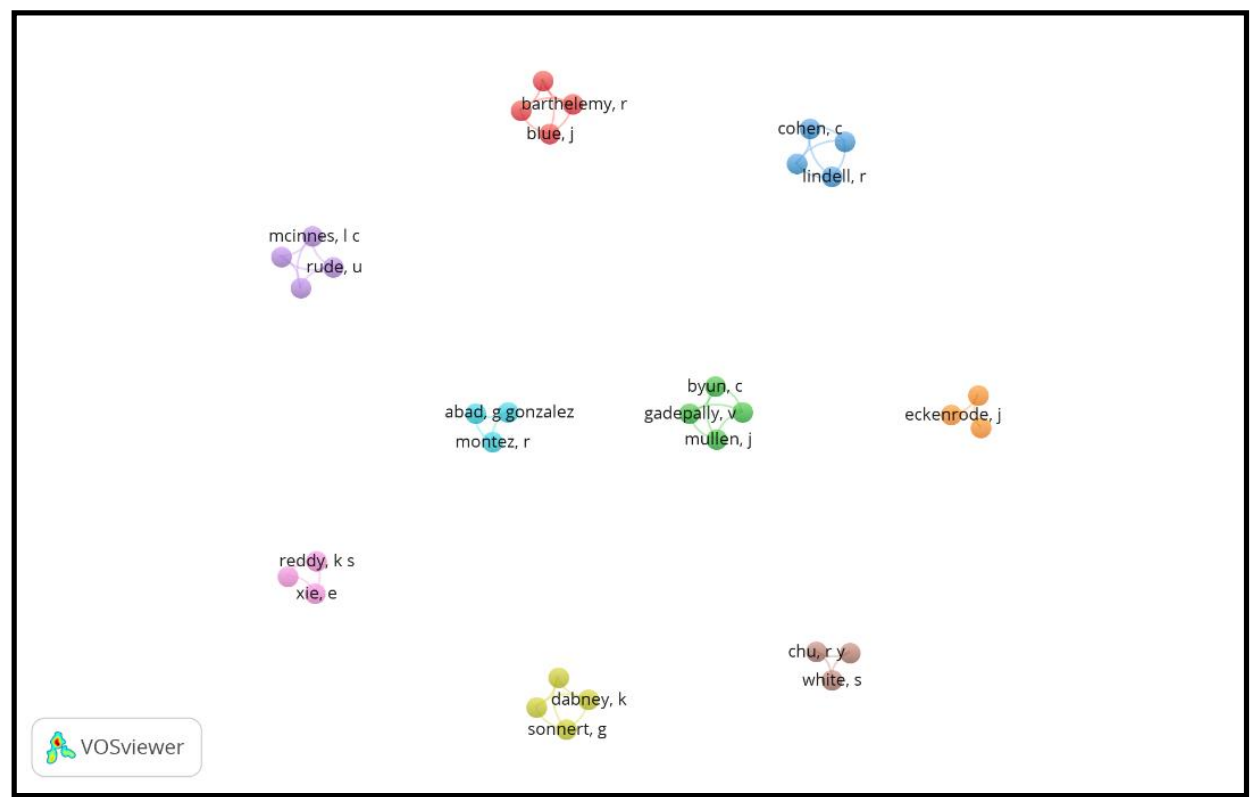

Figure 5. Visualization of authorship relationship analysis and collaboration patterns between writer.

Based on Figure 5, there are already many authors who have co-author relationships. However, there are still no authors who collaborate with other groups on the keywords of astrophysics education. The analysis of the update of publications in the form of a time overlay is visualized in Figure 6.

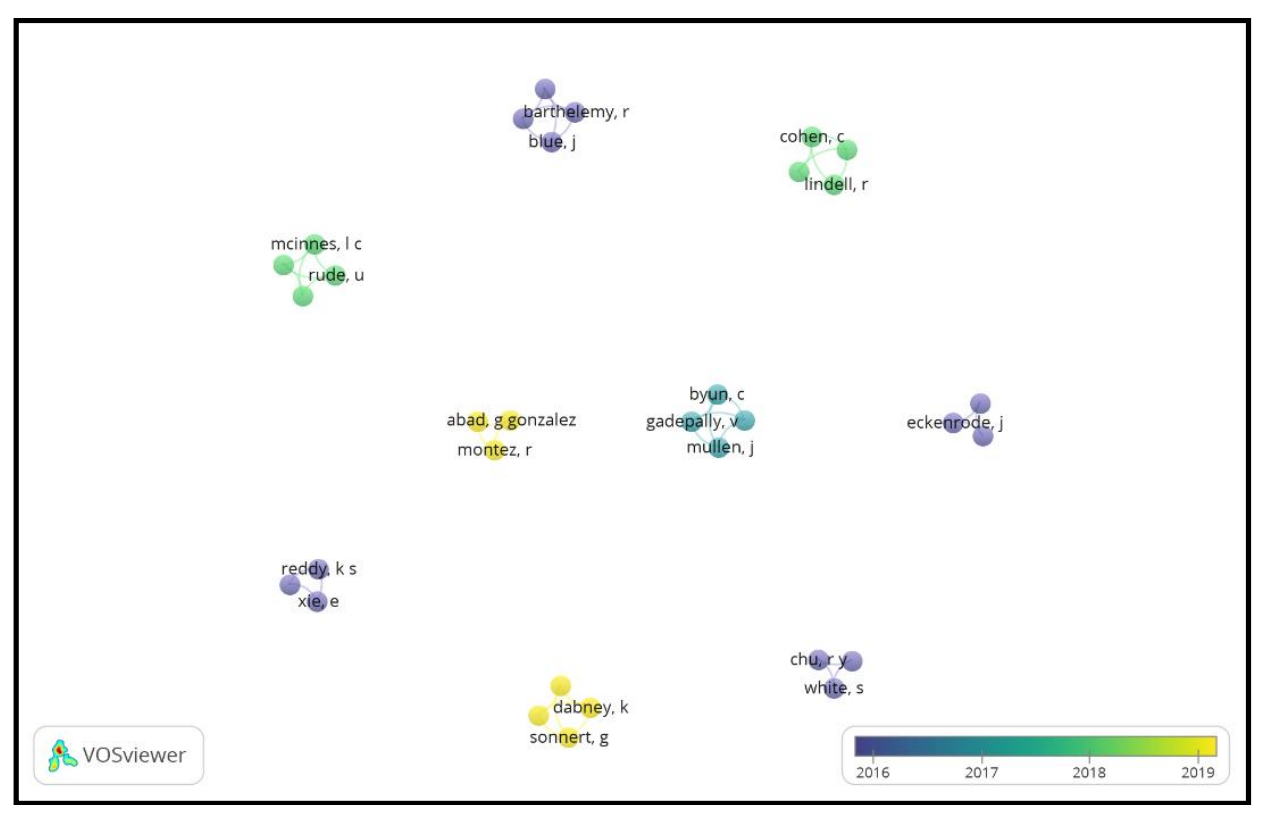

Figure 6. Visualization of the time of writing and the pattern of collaboration between authors.

Figure 6 shows the most recent astrophysics education keywords researched by the yellow pattern, namely by G. Gonzalez Abad, C. Crowley and R. Montez and by R. Dou, K. Dabney, Z. Hazari, and G. Sonnert. The other colors don't mean that other research 
Bibliometric Analysis in Astrophysics: Overview of Education, Religion, and Local Wisdom in 2016$2021^{*}$

has gone too long. The yellow color simply indicates that the research was published two years before 2021 .

The keywords used in English aim to map the extent to which these keywords are written globally, of course, published by international journals. An analysis was also conducted on publishers who contributed the most articles in the last six years. Of the 23 articles sorted, 3 articles were published by the journal Physical Review Education Research and 3 other articles were published by the American Astronomical Society Meeting Abstracts \#228. This shows that these two journals are active in publishing articles on astrophysics education.

If studied Islamically, the Qur'an has guided so that humans pay attention to the universe, pay attention to the universe as well as studying physics which is a form of reading God's verses and leads to dhikrullah (Anwar and Elfiah, 2019; Rasyid, 2020). Indeed, the Qur'an does not separate general knowledge from Islamic religious knowledge but sees it as a unitary entity from the universe (Anwar and Elfiah, 2019; Lailiyah, 2020). The new transformationalism in Islam is expected to strengthen the relationship between faith and rationality which has been submerged because scientific investigations are not used as a medium to increase faith (Sabic-El-Rayess, 2020).

There are several conditions that must be applied if you want to explain the verses of the Qur'an related to scientific facts so that they can be accepted in faith and rationality. First, the Qur'an remains the basis of guidance that is not diminished by scientific explanations. Second, scientific explanations act as a bridge to strengthen the message of the verses of the Qur'an so as to prevent deviations from faith. Third, it must be understood that the Qur'an is a book of guidance, not a book of knowledge directed at understanding the greatness of Allah through the universe He created. Fourth, scientific explanations play a role as elaboration of verse explanations, not interpretations of the Qur'an, so that if it turns out to be contrary to scientific facts it will not reduce the sanctity and absolute truth of the Qur'an (Maimun, 2019).

Kauniyah verse-based science learning is proven to significantly improve students' scientific communication skills, which is one of the 21st century skills (Fadly and Rochmahwati, 2020). If religious values are instilled from an early age in an integrative way with general science, then religion will become a solid foundation for the construction of science and technology (Fadly and Rochmahwati, 2020). Talking about science cannot be separated from talking about astronomy which is the structure and epistemology of Islamic law which studies the sun, moon, stars, and celestial bodies related to aspects of Islamic law (Chotban, 2020). Research results show that astrophysics teaching materials can be used physically or independently, online or offline and can train students' critical thinking skills (Nirahua et al., 2020).

Indonesia is known to be rich in culture and local wisdom of each region. This is a very good potential. Physics material associated with local wisdom will make students know more about the richness of the culture in which they live and of course bring learning to a higher level of meaning (Navisah et al., 2021; Zainuddin et al., 2018). Local wisdom, if properly processed, can be a source of meaningful contextual learning (Saparini et al., 2021). Especially in astrophysics, the data and knowledge obtained cannot be used directly in other fields without considering the challenges and characteristics of the field (Zuiderwijk and Spiers, 2019). The results of the research show that the solar system module containing the verses of the Qur'an is suitable to be used to train the character of students' local wisdom (Mastuang et al., 2019). Learning local wisdom is synonymous 
with a life-based approach. The results of the research show that the direct learning model taught with a life-based approach can improve student learning outcomes (Kastur et al., 2020). One way to integrate science, religion, and local wisdom is to invite students to work together to water plants and clean up trash during the learning process (Bjuri et al., 2020). The values of local wisdom can also be integrated through the verses of the Qur'an in learning (Mastuang et al., 2019). Through learning that integrates religion, science, and local wisdom makes learning meaningful and level up so as to prove that Islam not only regulates worship but also provides knowledge for the good of mankind through the Qur'an and Hadith (Bjuri et al., 2020).

\section{CONCLUSIONS}

Network visualization analysis is based on the emergence of keyword pairs which explain that each cluster with the same color has keywords that are closely related to each other than to other color clusters (Liu et al., 2015). Analysis of collaboration patterns between authors is often used in bibliometric research to identify common areas of research (Hudha et al., 2020). Based on the keywords that appear in the network visualization, it seems that there are no keywords that lead to religion or local wisdom. This indicates that research on astrophysics education that contains religious or religious content and local wisdom has not been widely studied.

In general, the data obtained can provide an overview of research trends in astrophysics education in the field of education in the last 6 years. Some suggestions that can be given by researchers for future research are to develop teaching materials containing verses from the Qur'an and local wisdom and to correct erroneous understandings of science by studying it from the perspective of the Qur'an. The limitation of this research is that it has not been able to sort search results by city and author affiliation. In addition, suggestions can be given for further research in order to develop keywords used in sorting a topic, for example by city, affiliation, and country so that the results obtained through bibliometric analysis are more comprehensive (Hudha et al., 2020). The gap in this study shows the direction of future projections that astrophysics education is very feasible to be studied with religious content based on the Qur'an and local wisdom and collaborating not only between national institutions but also internationally.

\section{ACKNOWLEDGE}

Researchers would like to thank the Universitas Lambung Mangkurat for funding PNBP University in 2021, in the program "Dosen Wajib Meneliti", with contract No: 009.117/UN8.2/PL/2021.

\section{REFERENCES}

Anwar, S., \& Elfiah, R. (2019). Science and religious integration (implications for the development at UIN Raden Intan Lampung). Journal of Physics: Conference Series, 1155(1), 1-9. https://doi.org/10.1088/1742-6596/1155/1/012095

Aydinoglu, A. U., \& Taşkın, Z. (2018). Origins of life research: A bibliometric approach. Origins of Life and Evolution of Biospheres, 48(1), 55-71. https:// doi.org/10.1007/s11084-017-9543-4

Baneyx, A. (2008). Publish or perish as citation metrics used to analyze scientific output in the humanities: International case studies in economics, geography, social sciences, 
Bibliometric Analysis in Astrophysics: Overview of Education, Religion, and Local Wisdom in 2016$2021^{*}$

philosophy, and history. Archivum Immunologiae et Therapiae Experimentalis, 56(6), 363-371. https:// doi.org/10.1007/s00005-008-0043-0

Benz, A. O. (2017). Astrophysics and creation: Perceiving the universe through science and participation. Zygon, 52(1), 212-231.

Prahani, B. K., Mahtari, S., Suyidno, Siswanto, J., \& Kristiyanto, W. H. (2020). Metaphysics in a review of "karl popper's philosophy of science" (rationality without foundations) by stefano gattei. IJORER: International Journal of Recent Educational Research, 1(3), 314-318. https://doi.org/10.46245/ijorer.v1i3.58

Bujuri, D., Baiti, M., \& Baharudin, B. (2019). Model pembelajaran ilmu pengetahuan alam integratif berbasis kearifan lokal di sekolah dasar. Prosiding Seminar Nasional STKIP PGRI Bandar Lampung, 2(1), 285-302.

Chotban, S. (2020). Membaca ulang relasi sains dan agama dalam perspektif nalar ilmu falak. Elfalaky: Jurnal Ilmu Falak, 4(2), 222-232.

Chusni, M. M., Amelia, A., Azizah, D. S., Zafira, K. F., \& Agustina, R. D. (2018). Fenomena entropi dilihat dari perspektif sains dan Al-Qur'an. SPEKTRA: Jurnal Kajian Pendidikan Sains, 4(2), 105-110. https://doi.org/10.32699/spektra.v4i2.51

Dona, P., \& Syafriani, S. (2020). Analysis of physics e-modules based on guided inquiry integrated with quran knowledge. Journal of Physics: Conference Series, 1481(1), 1-3. https://doi.org/10.1088/1742-6596/1481/1/012060

Fadly, W., \& Rochmahwati, P. (2020). Kauniyah verse-based science learning: Reconstruction of the 21th century science learning program. Journal of Physics: Conference Series, 1567(4), 1-6. https:/ / doi.org/10.1088/1742-6596/1567/4/042035

Garza-Reyes, J. A. (2015). Lean and green-a systematic review of the state of the art literature. Journal of Cleaner Production, 102(1), 18-29. https://doi.org/10.1016/j.jclepro.2015.04.064

Hamidah, I., Sriyono., \& Hudha, M. N. (2020). A bibliometric analysis of covid-19 research using vosviewer. Indonesian Journal of Science and Technology, 5(2), 209-216.

Henneken, E., \& Kurtz, M. J. (2019). Usage bibliometrics as a tool to measure research activity in Springer Handbook of Science and Technology Indicators. https:/ / doi.org/10.1007/978-3030-02511-3_19

Hudha, M. N., Hamidah, I., Permanasari, A., Abdullah, A. G., Rachman, I., \& Matsumoto, T. (2020). Low carbon education: A review and bibliometric analysis. European Journal of Educational Research, 9(1), 319-329. https://doi.org/10.12973/eu-jer.9.1.319

Kastur, A., Mustaji, \& Riyanto, Y. (2020). Feasibility of developing direct learning models with a life based learning approach. IJORER: International Journal of Recent Educational Research, 1(3), 261-270. https://doi.org/10.46245/ijorer.v1i3.63

Lailiyah, S. (2020). Keilmiahan sains adalah bukti kebenaran Al Qur'an. Prosiding Seminar Nasional Pendidikan Fisika FITK UNSIQ 2020, 2(1), 204-216.

Liu, Z., Yin, Y., Liu, W., \& Dunford, M. (2015). Visualizing the intellectual structure and evolution of innovation systems research: A bibliometric analysis. Scientometrics, 103(1), 135-158. https://doi.org/10.1007/s11192-014-1517-y

Lizelwati, N., \& Chandra, A. N. (2019). Developing instructional devices of general physics practicum integrated with Al-Quran for department of physics education IAIN Batusangkar. Journal of Physics: Conference Series, 1185(1), 1-9. https://doi.org/10.1088/1742-6596/1185/1/012039

Maimun, A. (2019). Integrasi agama dan sains melalui (mempertimbangkan signifikansi dan the integration of religion and science in tafsīr 'ilmī (considering the significances and critiques). Anil Islam: Jurnal Kebudayaan dan Ilmu Keislaman, 12(1), 36-62.

Mastuang, M., Misbah, M., Yahya, A., \& Mahtari, S. (2019). Developing the physics module containing quranic verses to train the local wisdom character. Journal of Physics: Conference Series, 1171(1), 1-7. https:// doi.org/10.1088/1742-6596/1171/1/012018 
Mohan, B. S., \& Rajgoli, I. U. (2017). Mapping of scholarly communication in publications of the astronomical society of Australia, publications of the astronomical society of Japan, and publications of the astronomical society of the pacific: A bibliometric approach. Science and Technology Libraries, 36(4), 351-375. https:// doi.org/10.1080/0194262X.2017.1368427

Mukri, M., Faisal, F., Anwar, S., \& Asriani, A. (2019). Quran-integrated science in the era of industrial revolution 4.0. Journal of Physics: Conference Series, 1155(1), 1-5. https:// doi.org/10.1088/1742-6596/1155/1/012001

Navisah, S., Wati, M., \& M, A. S. (2021). Developing circular motion physics module integrated with gumbaan local wisdom in cooperative learning setting to improving learning achievement. Berkala Ilmiah Pendidikan Fisika, 9(1), 47-56. https://doi.org/10.20527/bipf.v9i1.8450

Nirahua, J., Taihuttu, J., \& Sopacua, V. (2020). Pengembangan bahan ajar berbasis blended learning dan critical thinking skill pada mata kuliah astrofisika dalam menyongsong era revolusi industri 4.0. Jambura Physics Journal, 2(1), 24-36. https://doi.org/10.34312/jpj.v2i1.6869

Rasyid, A. N. (2020). Astronomi dan kosmologi dalam perspektif Al-Qur'an. VEKTOR: Jurnal Pendidikan IPA, 1(1), 39-49. https:/ / doi.org/10.35719/vektor.v1i1.3

Sabic-El-Rayess, A. (2020). Epistemological shifts in knowledge and education in Islam: A new perspective on the emergence of radicalization amongst Muslims. International Journal of Educational Development, 73(1), 1-10. https:/ / doi.org/10.1016/j.ijedudev.2019.102148

Saparini, S., Syuhendri, S., \& Murniati, M. (2021). Conceptual change textbook based on local wisdom of palembang on heat and temperature. Berkala Ilmiah Pendidikan Fisika, 9(1), 88-95. https://doi.org/10.20527/bipf.v9i1.9568

Setyaningsih, I., Indarti, N., \& Jie, F. (2018). Bibliometric analysis of the term "green manufacturing". International Journal of Management Concepts and Philosophy, 11(3), 315-339. https://doi.org/10.1504/ijmcp.2018.093500

Soleh, A. K. (2018). Pendekatan kuantum dalam integrasi agama dan sains nidhal guessoum. ULUL ALBAB Jurnal Studi Islam, 19(1), 119-141. https:/ / doi.org/10.18860/ua.v19i1.4937

Toresano, W. O. Z. Z. (2020). Integrasi sains dan agama: Meruntuhkan arogansi di masa pandemi covid-19. Maarif, 15(1), 231-245. https:// doi.org/10.47651/mrf.v15i1.87

Van Eck, N. J., \& Waltman, L. (2010). Software survey: VOSviewer, a computer program for bibliometric mapping. Scientometrics, 84(2), 523-538. doi.org/10.1007/s11192-009-0146-3

Wahid, K., Mohd Nawawi, M. S. A., \& Man, S. (2016). Interpretation and views of quranic commentaries on the planet based on al-kawkab and al-kawakib terms. Al-Shajarah, 21(1), 91-113.

Zaelani, K. (2015). Philosophy of science actualization for Islamic science development. Pacific Science Review B: Humanities and Social Sciences, 1(3), 109-113. https://doi.org/10.1016/j.psrb.2016.06.004

Zainuddin, D., Afnizar, H. A., Mastuang, D., \& Misbah, D. (2018). Developing a teaching material oriented to science and technology and local wisdom in wetland environment. Proceedings of the 1st International Conference on Creativity, Innovation and Technology in Education (IC-CITE 2018), 274(1), 323-325. https:// doi.org/10.2991/iccite-18.2018.68

Zuiderwijk, A., \& Spiers, H. (2019). Sharing and re-using open data: A case study of motivations in astrophysics. International Journal of Information Management, 49(2), 228-241. https://doi.org/10.1016/j.ijinfomgt.2019.05.024

\footnotetext{
*Zainuddin (Corresponding Author)

Physics Education, Faculty of Teacher Training and Education,

Lambung Mangkurat University,

Jl. Brigjen H. Hasan Basri, Banjarmasin, South Borneo, 70123, Indonesia

Email: zainuddin_pfis@ulm.ac.id
} 
Bibliometric Analysis in Astrophysics: Overview of Education, Religion, and Local Wisdom in 2016-

\section{Surya Haryandi}

Physics Education, Faculty of Teacher Training and Education,

Lambung Mangkurat University,

Jl. Brigjen H. Hasan Basri, Banjarmasin, South Borneo, 70123, Indonesia

Email: surya.haryandi@ulm.ac.id

\section{Misbah}

Physics Education, Faculty of Teacher Training and Education,

Lambung Mangkurat University,

Jl. Brigjen H. Hasan Basri, Banjarmasin, South Borneo, 70123, Indonesia

Email: misbah_pfis@ulm.ac.id

\section{Mastuang}

Physics Education, Faculty of Teacher Training and Education,

Lambung Mangkurat University,

Jl. Brigjen H. Hasan Basri, Banjarmasin, South Borneo, 70123, Indonesia

Email: mastuang_pfis@ulm.ac.id

\section{Mohd Ali Ibrahim}

Physics Eduction, Universiti Teknologi Malaysia, Malaysia

Sultan Ibrahim Chancellery Building, Jalan Iman, 81310 Skudai, Johor, Malaysia

Email:p-mali@utm.my

\section{Emy Nur Juliana}

Physics Education, Faculty of Teacher Training and Education,

Lambung Mangkurat University,

Jl. Brigjen H. Hasan Basri, Banjarmasin, South Borneo, 70123, Indonesia

Email: emyjuliana2233@gmail.com

\section{Munawarah}

Physics Education, Faculty of Teacher Training and Education, Lambung Mangkurat University,

Jl. Brigjen H. Hasan Basri, Banjarmasin, South Borneo, 70123, Indonesia

Email: munawarah.naw99@gmail.com

\section{Ma'rifah Hidayati}

Physics Education, Faculty of Teacher Training and Education,

Lambung Mangkurat University,

Jl. Brigjen H. Hasan Basri, Banjarmasin, South Borneo, 70123, Indonesia

Email: rifahhidayati99@gmail.com 